\title{
Educational Assortative Mating in Hong Kong: 1981-2011
}

\author{
Muzhi Zhou, University of Oxford
}

Address correspondence to Muzhi Zhou, St Antony's College, 62 Woodstock Road, Oxford OX2 6JF, United Kingdom. E-mail: muzhi.zhou@sant.ox.ac.uk

\section{Abstract}

This article documents trends in educational assortative mating using samples of the 1981 to 2011 Hong Kong population censuses/by-censuses, with a particular focus on specific education group and the Hong Kong-mainland China cross-border marriages. Results show an overall declining trend in educational assortative mating, which is driven mostly by the great increase of intermarriage between those with associate qualifications and those with lower secondary or less levels of education. Growing number of cross-border marriages is also accompanied by the substantive decline in educational homogamy for women from mainland China in recent years. It implies that immigrants from mainland China are more likely to exchange education for the Hong Kong permanent residency by marrying spouses with less education in Hong Kong. These findings suggest that a general declining trend in educational assortative mating does not necessarily indicate the weakening of social boundaries and an increased openness of a society.

The author is deeply grateful to Mr. Colin Mills from the University of Oxford, Professor Xiaogang Wu from the Hong Kong University of Science \& Technology (HKUST), and the anonymous reviewers for their comments and suggestions on this article. The author also extends sincere thanks to the financial support from the Swire Educational Trust. The data access is made possible by the RGC-CPU Strategic Public Policy Research Fund (HKUST6001-SPPR-08) via the Center for Applied Social and Economic Research, HKUST. 


\section{Introduction}

Marriage can be viewed as a process of resource recombination in which the socioeconomic status, cultural backgrounds, or other qualities of two families are pooled and accumulated (Oppenheimer 1988). Homogamy or assortative mating, which refers to the marriage pattern that people with similar resources marry with each other, dominates modern societies. Rates of homogamy are important indicators of the degree of exclusion and measures of the rigidity of social boundaries (Blossfeld 2009; Kalmijn 1998; Schwartz and Mare 2005; Smits 2003), Educational assortative mating has received particular attention because education plays a key role in determining socioeconomic outcomes, in structuring marriage markets, and in the intergenerational transmission of social status (e.g., Blossfeld 2009; Bourdieu 1977; Kalmijn 1998; Kalmijn and Flap 2001; Liu and Zhang 1999; Mare 1991; Schwartz 2013; Smits, Ultee and Lammers 2000). Two general theories have been proposed for the studies of trends in educational assortative mating along with the modernization process. The "general openness hypothesis" claims a fading away of social boundaries and an increase in contacts across various social groups in the process of modernization, and thereby predicts a declining trend in educational assortative mating (Smits, Ultee and Lammers 1998). The "status attainment hypothesis", on the other hand, predicts an increase in educational homogamy, emphasizing the condition that education becomes an increasingly important predictor of socioeconomic success in the industrialization process (Smits, Ultee and Lammers 1998). There have been concerns that increase in educational resemblance of spouses may contribute to the growing income and educational inequality (e.g., Albertini 2008; Breen 2011; Greenwood et al. 2014; Schwartz 2010; Torche 2010).

Empirical evidence regarding the trends in educational assortative mating, however, is more diversified than the trends predicted by the two general theories above. Almost all possibilities of trends in educational assortative mating, either increase, decrease, U-shaped, or inverted-U shaped, have been found either for one country in the modernization process over time (e.g. Han 
2010; Kalmijn 1991a; Kalmijn 1991b; Mare 1991; Rosenfeld 2008; Schwartz and Mare 2005;

$\mathrm{Xu}, \mathrm{Li}$ and $\mathrm{Yu}$ 2014) or across different countries ranked by their levels of modernization (e.g.

Raymo and Xie 2000; Smits 2003; Smits, Ultee and Lammers 1998). Even for countries at similar levels of development, the results are still mixed (e.g. Katrnák, Kreidl and Fónadová 2006). One possible reason for the inconsistent findings is the dramatic improvement in education, which makes it difficult to generalize a single trend in educational assortative mating. The rigidity of social boundaries of different education groups may not change uniformly, for example, certain education groups could retain their social closeness while levels of homogamy decline among other education groups (Blossfeld 2009; Halpin and Chan 2003; Park and Smits 2005). At a time of extensive educational expansion, it is necessary to evaluate more specific changes in educational assortative mating for different education groups.

Despite of the significance of educational homogamy, past research is largely concentrated on the United States, a few European countries and some cross-national comparative studies (e.g., Halpin and Chan 2003; Schwartz and Mare 2005; Smits and Park 2009; Smits, Ultee and Lammers 1998; Smits, Ultee and Lammers 2000). As a diverse society where east meets west, Hong Kong was only included in cross-national comparative study as a small case in East Asia (e.g., Smits 2003; Smits and Park 2009). Rarely was there an in-depth study on marriage patterns in Hong Kong beyond simple descriptive tables (e.g., Pong et al. 2014).

The changing marriage pattern in Hong Kong deserves a special attention because assortative mating is often linked to socioeconomic inequality, for which the city has been plagued with since the 1990s. The Gini coefficient in Hong Kong, which is a common measure of income inequality, has been steadily increasing for years, from 0.45 in 1981 to 0.53 in 2006, and is significantly higher than that in most developed countries (Wu 2009, p 1034). During the same period, education in Hong Kong has expanded substantially, being transformed from an elite-oriented system to a mass-oriented system (Wu 2007). The colonial government started 
providing free primary and compulsory education to children aged 6 to 11 years old in 1971, and then extended the policy to the lower secondary level in 1978 (Post 1994). Following the expansion of secondary education, the government decided to triple the enrolments in higher education in 1989, and the number of tertiary institutions funded by the government increased from 2 to 8 to in the 1990s. Like what have happened in many western countries, the expansion of higher education tends to benefit women greatly and more women are able to receive college education in Hong Kong (Wu 2007), which greatly increases the supply of highly educated women in local marriage markets and affects the patterns of assortative mating in the city. More notably, because the majority of the population in the territory is ethnic Chinese, of which one-third emigrated from mainland China, cross-border marriages dominated by Hong Kong grooms-mainland brides had been popular between Hong Kong locals and mainland Chinese (Zhang and $\mathrm{Wu}$ 2011). The immigration policy change in 1983, which installed one-way permit quota system, enabled qualified mainlanders to come to Hong Kong for family reunion in an orderly manner. As a result, the increase in adult new arrivals was mostly women coming to join their husbands, and cross-border marriage continues to increase since Hong Kong's handover to Chinese sovereignty in 1997 (Lin and Má 2008; So 2003). Therefore, immigration associated with cross-border marriage is likely to yield important impact on the marriage patterns in Hong Kong.

In this article, I provide a comprehensive examination of changes in educational assortative mating in Hong Kong during 1981 to 2011. Based on seven waves of repeated cross-sectional data from population censuses and by-censuses, I present both a general trend in educational assortative mating and specific changes in marriage patterns for different education groups. I include changes of the in-group marriages (educational homogamy) as well as changes of the cross-group marriages (educational heterogamy). Given the prevalence of cross-border marriage in Hong Kong, I also examine its role in shaping the patterns of assortative mating in the territory. 


\section{Industrialization, Educational Expansion, and Assortative Mating}

During the late 1940s to 1980s, Hong Kong had been transformed from a territory of entrepôt trade to one of extensive light industry and manufacturing. Starting from the 1980s, with the open door policy enacted in mainland China, manufactures in Hong Kong began its relocation to the mainland, and were replaced subsequently by service sector such as retail, trade, property, finance and banking. People with university qualifications enjoyed a great income growth in professional and managerial occupations. The "status attainment hypothesis" predicts that the ascribed characteristics (e.g., race/ethnicity, religion) are getting less important, while achieved characteristics (e.g., education) are getting more important in achieving success as societies develop (Smits, Ultee and Lammers 1998). Therefore, people should be increasingly more likely to select a better-educated partner to retain socioeconomic advantages. As a result of such competition, people with similar educational attainment are squeezed together (Smits, Ultee and Lammers 1998). In addition, the increase in income inequality may have reduced the likelihood of educational intermarriage by increasing the social and economic distance between education groups (Rytina et al. 1988; Schwartz 2013; Smits, Ultee and Lammers 1998). In general, an increase in educational assortative mating should be expected in the context of Hong Kong.

Meanwhile, Hong Kong has also witnessed extensive educational expansion during the same period and the overall improvement of education requires a more detailed discussion of changes in educational homogamy. During this period, the percentage of people aged 20 or above with upper secondary educational attainment increased from 35.2 percent in 1986 to 61.9 percent in 2011(Chua, Wong and Shek 2010) . When university graduates were highly demanded in the labor market and university degree guaranteed higher economic returns, an initial surge in educational homogamy for people with university qualification should be observed. However, as education continues to expand and more skilled labors are available, increases in economic returns to university qualification should slow down. Therefore, the level of educational 
homogamy for university graduates may stabilize in later periods. On the other hand, certain educational qualifications which used to be highly rewarded, such as the associate degrees in the post-secondary qualifications, may experience substantial depreciation when more people of university education came to reap their previous advantages in the labor market. Researchers have found that homogamy will decrease as highly educated groups have expanded to a level to become less exclusive (Smits 2003; Smits and Park 2009). In sum, with industrial restructuring and continuous educational expansion, the levels and directions of changes in educational assortative mating vary by different education groups.

\section{Immigration, Cross-border Marriages and Assortative Mating}

One feature that distinguishes Hong Kong from many other developed societies is its significant portion of mainland Chinese immigrants over the past century. Most immigrants are from the neighboring Guangdong province sharing the same ethnic identity and dialect as the natives in Hong Kong. Yet the process of cross-border migration from mainland China to Hong Kong, once a British colony and now a Special Administrative Region (SAR) of China under the principle of "one country, two systems", resemble that of international migration between two countries to a large extent, the same ethnicity and culture shared by mainland Chinese and natives in Hong Kong minimized the barriers to economic and social integration to Hong Kong society and created the condition of high levels of affinity to which no international migrations can compare (Zhang and Wu 2011).

Along with the long-standing migration history and political turbulences, the reasons, the purposes, and the consequences of immigration keep evolving. After the liberation of Hong Kong from Japanese occupation in the late 1940s, many well-educated mainland Chinese immigrants came to Hong Kong as refugees during and after the civil war period. The skills and capital brought by those immigrants helped Hong Kong's revival in the 1950s. In late 1950s and early 
1960s, the chaotic political movement and famine in mainland China drove a large number of immigrants and refugees to Hong Kong. Strict border control policies were once implemented but soon abandoned in 1967 because of the labor shortages faced by the Hong Kong manufacturing industry. Most immigrants and refugees were absorbed into the manufacturing sector and granted permanent residency (So 2003). From 1974 to 1980, a "touch-base" policy was implemented and immigrants were allowed to apply for identification cards, reside and work in Hong Kong once they managed to reach the urban areas of Hong Kong. After 1980, the number of unauthorized immigrants from mainland China decreased dramatically due to the more rigorous immigration control. Meanwhile, mainland China started its open-door policy and more contacts between Hong Kong and mainland China beyond the borders make the cross-border marriages popular between Hong Kong locals and mainland Chinese. ${ }^{1}$ The proportion of cross-border marriages over total Hong Kong registered marriages went from 20.0 percent in 1986 to 55.8 percent in 2006 (Census and Statistics Department 2012). ${ }^{2}$ Those cross-border marriages have been dominated by Hong Kong grooms-mainland brides. Since the 1990s, most arrivals of the Chinese immigrants, predominantly female and children came to Hong Kong for family reunion (So 2003).

Exchange theory of mate selection argues that people will balance unequal traits through exchange in a way that a relative disadvantage in one domain is "exchanged" for a relative advantage in another domain (Davis 1941; Merton 1941). For example, people may exchange advantaged race in the marriage market for education in a way that better educated people in a disadvantaged racial group marry those less educated from an advantaged racial group. Empirical evidence also finds such exchange reflected as negative assortative mating in those interracial and international marriages (e.g. Alba and Golden 1986; Gullickson and Torche 2014; Qian and Lichter 2001). 
When the gap in living standards between Hong Kong and mainland China remains substantial, the change of goals of immigration policy from labor-import to family-reunion makes cross-border marriage a relative ideal arena to play status exchange in which the Hong Kong permanent residency is considered relatively "advantaged". The much more restrictive immigration control and the launch of the one-way permit quota system in 1983 enabled qualified mainlanders to come to Hong Kong for family reunion purposes. For mainland Chinese adults with no relatives in Hong Kong, being a Hong Kong resident's spouse was the most likely way to immigrate to Hong Kong. In addition, earlier immigrants, particularly men being absorbed in the manufacturing industry, were not favored both in the labor market and in the marriage market when Hong Kong has completed its shift from manufacturing base to service and financial center. They started their search for spouse in mainland China and their Hong Kong residence status could be attractive to those from the relatively less developed areas in China. Also, the traditional gender ideology makes it more socially acceptable for women to follow their breadwinner husbands and to reside in Hong Kong as homemakers. I therefore expect an increasing trend in negative assortative mating in which more selective group of spouses from mainland China, particularly women, exchange their education for Hong Kong permanent residency by marrying less educated men in Hong Kong in later periods.

\section{Data, Variables, and Methods}

I analyze a subsample of the population censuses or by-censuses in Hong Kong from 1981 to 2011, which contain consistent measures of marital status, education, birthplace, and ethnicity. The population census is conducted in every ten years, and the by-census is conducted midway between two censuses. Prior to 1990, only the one percent sample was released to the public; since 1991, the sample has been increased to five percent. Married couples in the samples were selected based on the following considerations. In Hong Kong, while it is legal to marry from age 
15 , it is quite rare to find people married at such young age. For couples of wives over age 60 , the sample may be too heterogeneous due to the differential mortality. To describe the overall trend in educational assortative mating, married women aged from 21 to 60 were matched with their co-residing husbands, and a total number of 314,191 couples was obtained in the end. ${ }^{3}$ I further divided the selected couples into those of mainland-born wives and those of Hong Kong native wives to evaluate the exchange theory in subsequent analysis. Education was classified into five levels: primary or less, lower secondary, upper secondary, associate, and university.

Log-linear models are suitable for analyzing the tables cross-classifying wife's education by husband's education and grouped by year of census and/or by wife's birth place. These models assume that the expected counts in the marriage table are multiplicative function of the sample size, the number of wives in a group, the number of husbands in a group, and an interaction parameter, which measures marriage selection independent of the marginal row and column distributions (Kalmijn 1998). In addition to the conventional model specifications using design matrices, I also employ the log-multiplicative row and column effects specification (RC model). The advantage of using this RC model specification is that the row and column interaction can be decomposed into the row and column scores to identify changes in relative positions across the educational system (Wong 2010).

For illustrative purpose, $R$ and $C$ in the following equations are used to denote wife's and husband's education as the row and column variable respectively. Year of census is the grouping variable denoted as $L$. The subscripts $i, j$, and $k$ are used to identify parameters corresponding to the $i$ th row, $j$ th column, and/or $k$ th layer. The log-multiplicative layer effect model or the UNIDIFF model is used to detect the existence of group differences (Xie 1992). The basic log-linear equation for this model can be written as:

$$
\log F_{i j k}=\mu+\mu_{i}^{R}+\mu_{j}^{C}+\mu_{k}^{L}+\mu_{i k}^{R L}+\mu_{j k}^{C L}+\emptyset_{k} \varphi_{i j}^{R C}
$$


where $F_{i j k}$ is the expected frequency for the cell indexed by the $i$ th row, $j$ th column, and $k$ th layer. Parameters $\mu, \mu_{i}^{R}, \mu_{j}^{C}, \mu_{k}^{L}, \mu_{i k}^{R L}$, and $\mu_{j k}^{C L}$ represent the logarithms of the marginal effects of the sample size, wife's education, husband's education, year of census, and their two-way interactions respectively. $\emptyset$ is the layer specific scale factor of the row and column association and $\varphi$ describes the association between wife's education and husband's education (Xie 1992). If we would like to capture the structural features of educational assortative mating, explicit structure such as the various design matrices can be specified for $\varphi$.

When wife's birthplace is taken into consideration, the same equation applies but to two subsets of the tables separately. One is a subset of couples with wives born in Hong Kong and another is a subset of couples with mainland-born wives. The layer specific scale factors from the two subsets of tables are set to the same reference point for comparison purpose (Xie 1992).

$\mathrm{RC}$ model specification is employed to decompose $\varphi$ in Equation 1 in order to disentangle the interaction of wife's and husband's education into two sets of scores of education for wife and husband respectively. The scores empirically obtained from data can be interpreted as the optimal “assortative mating distances” between educational levels (Torche 2010). Under this specification, Equation 1 is transformed into

$$
\log F_{i j(k)}=\mu+\mu_{i}^{R}+\mu_{j}^{C}+\mu_{k}^{L}+\mu_{i k}^{R L}+\mu_{j k}^{C L}+\sum_{m=1}^{M} \emptyset_{m k} \sigma_{i m} \vartheta_{j m}
$$

where $\sigma_{i m}$ and $\vartheta_{j m}$ are the score parameters for the $i$ th row and $j$ th column for the $m$ th dimension. They are set to be the same across layer and only the intrinsic association parameter $\emptyset$ varies with time. This "simple heterogeneous" setting is of great value. Because instead of outputting more than one parameter at each layer, this setting gives one unique parameter $\emptyset_{k}$ for each layer which represents the strength of the row and column association at layer $k$ in dimension $m$ (Wong 2010, p90). 
In this article, the maximum dimensions considered under the $R C(M)-L$ realm is $2(M=2)$. Therefore, Equation 2 can be reduced to

$$
\log F_{i j(k)}=\mu+\mu_{i}^{R}+\mu_{j}^{C}+\mu_{k}^{L}+\mu_{i k}^{R L}+\mu_{j k}^{C L}+\emptyset_{1 k} \sigma_{i 1} \vartheta_{j 1}+\emptyset_{2 k} \sigma_{i 2} \vartheta_{j 2}
$$

This model would generate two sets of scores for wife's education and husband's education on each dimension respectively.

\section{Results}

\section{Descriptive Statistics}

Table 1 summarizes the demographic statistics for married women and their husbands in Hong Kong from 1981 to 2011. During this period, mean ages increased, but such increase was more remarkable among those born in Hong Kong, which is largely a result of the delay in entering marriage. Married people from mainland China are generally older than those born in Hong Kong, but the gap is getting narrower among the two groups of married women. Population aging is prominent for immigrant men from mainland China, whose mean age grew from 46 to 52 . The proportion of married men born in mainland in 2011 has declined to less than half of that in 1981, suggesting that the male immigrants are more likely to be in the older age cohorts and the influx has been greatly reduced over time. In our sample, the proportion of married men who came to Hong Kong for less than seven years of all mainland-born men dropped from 4.4 percent in 1981 to 2.1 percent in 1991 , and increased slightly to 3.8 percent in 2011 . Most of the male immigrants came to Hong Kong as cheap laborers at much younger age in earlier years and became Hong Kong permanent residents thereafter. While for married women from the mainland, the proportion of new comers surged from 8.4 percent in 1981 to over 20.0 percent in the 2000 s. Therefore, although many couples were both born in mainland China, their durations of stays in 
Hong Kong and residence status often differ, particularly in later periods. It is a typical form of the cross-border marriages from the 1990s in which a couple of a mainland-born husband with Hong Kong permanent residency marrying a wife recently coming from mainland China.

\section{[Table 1 about Here]}

Improvement in education is significant for both married women and men, especially for women. People born in Hong Kong enjoy an obvious advantage in education than those born in mainland China. The educational level of the immigrant population largely lagged behind that of those born in Hong Kong, and was getting even more severe over time. For example, the share of women with associate qualification among local wives increased exponentially from a 1.6 percent to 19 percent in thirty years. However, the proportion of immigrant women with university qualification changed from 2.0 percent to 7.9 percent only.

Table 2 shows the percentage distribution of wife's and husband's education by cross-classifying couple's education. Diagonal cells of Table 2, in which the wife and husband share the same educational level, occupy the highest percentage. It indicates that the marriage pattern is heavily dominated by educational homogamy. The share of homogamy for couple with "primary or less" level of education dropped tremendously from 48.3 percent to 11.4 percent in thirty years. Shares of homogamy for couples with other qualifications, however, showed different magnitudes of increase during this period.

[Table 2 Here]

To investigate changes in the tendency to marry within or out of education groups, couples in Table 2 are classified into homogamy, hypergamy in which the husband has more education than the wife, and hypogamy in which the wife has more education than the husband, respectively. Figure 1 shows the relative proportions of homogamy, hypergamy, and hypogamy in each year of 
census/by-census. Clearly, the proportion of hypogamous couples with more educated wives is growing, as a result of expanding educational opportunities favoring women.

[Figure 1 about Here]

However, the percentage change based on the above descriptive statistics should be interpreted with caution, because they may be highly influenced by changes in the marginal distributions of wife's and husband's education. For example, the fact that the proportion of homogamous couples was higher in 1981 than in other years may be a result of the high concentration of wives and husbands in the primary or less levels of education. Even with a constant association between wife's and husband's education, periods in which the marginal distributions are highly concentrated tend to produce a higher percentage of couples who share the same education (Schwartz and Mare 2005). Therefore, to identify changes in the strength of association between wife's and husband's education, log-linear models are used to estimate trends in assortative mating, controlling for changes in the marginal distributions of spouses' education.

\section{A General Trend in Educational Assortative Mating}

Table 3 presents the log-linear model specifications for a general trend in educational assortative mating in Hong Kong based on cell frequencies in Table 2. Both the $L^{2}$ and the Bayesian information criterion (BIC) for model fitness are provided but the BIC statistic is mainly used for model selection because of the large sample sizes (Raftery 1995). A more negative BIC value suggests a better model fitness. Model 1 in Table 3 (baseline model) assumes that the association of wife's and husband's education is time-invariant. It allows fully random row and column interaction except for the diagonal cells because of the large numbers accumulated at those cells. Parameters of the diagonal cells are estimated separately for better model fitness. Model 1 fits the 
model poorly relative to the following models that allow for changes in educational assortative mating over time.

\section{[Table 3 about Here]}

To examine the time-varying effect, the log-multiplicative layer-effect model or UNIDIFF model (Equation 1) is specified in Model 2, where the association between wife's and husband's education changes multiplicatively over years. The BIC value is substantially reduced. Also, with 6 additional degrees of freedom, the model explains $684(=1230-546) \chi^{2}$ points or 55.6 percent of the total variation in Model 1, clearly indicating that the association between wife's and husband's education is not the same across years. The seven scale factors with year 1981 as the reference are plotted in Figure 2, along with their respective quasi-confidence intervals for easy comparison (Firth 2003; Firth and Menzes 2004). ${ }^{4}$ Figure 2 suggests that the overall intensity of the educational assortative mating declined in the past three decades in Hong Kong, particularly after 1991. This result seems to be in contradictory to the "status attainment hypothesis", which predicts an increase in educational homogamy in the modernization process. Instead, it appears that the general declining trend supports the general openness hypothesis in Hong Kong.

[Figure 2 about Here]

Although Model 2 indicates a general decline in educational assortative mating, information on specific time-varying interaction structure is not provided. In Model 3, the quasi-symmetry model specification is imposed on the interaction term, assuming that the exchange of wife's education and husband's education is symmetrical for couples of different education (Powers and Xie 2008, p116), and this structure is set to vary with time multiplicatively. ${ }^{5}$ In addition, in East Asian societies, it is common that women tend to marry up while men tend to marry down (Smits and Park 2009). Model 4 consumes an additional degree of freedom to capture such tendency by assuming a common propensity for female hypergamy in the interaction term. ${ }^{6}$ Because the 
gender gap in education has continued to shrink, Model 4 further allows the hypergamy structure to change multiplicatively with time. ${ }^{7}$ For both Models 3 and 4, the parameters for the diagonal cells are estimated separately and change with time multiplicatively. BIC values show that Model 3 fits the data better and the symmetrical structure captures the most important time-varying features of the association between wife's and husband's education. The seven log-multiplicative scale factors of $\emptyset_{k}$ for the joint quasi-symmetrical interaction with layer are $0.92,0.88,0.82$, $0.78,0.74$, and 0.71 , showing a declined tendency of assortative mating among couples of different educational levels. Interestingly, the joint interactions of the main diagonal with layer are $1,1.18,1.25,1.13,1.08,1.05$, and 1.11 , respectively. In other words, levels of educational homogamy fluctuated, or even showed an increase between 1981 and 1991 and from 2006 onward. These results reveal the complication in changes in educational assortative mating over time, and the general openness hypothesis may not be able to comprehend.

\section{Trends in Educational Assortative Mating by Education Group}

At a time of extensive educational expansion, the general trend in educational assortative mating may ignore various changes in marriage patterns across different education groups. Therefore, it is necessary to evaluate changes in educational homogamy and heterogamy by each education group. I employ the RC model specification, where the scores of wife's and husband's education can be estimated empirically. Variant RC model specifications and fitness statistics are summarized in Table 4. In Table 4, RC(1)-L model (Equation 2 with one dimension) is specified in Model M1, where the scores of the row and column $\sigma$ and $\vartheta$ are fixed but the intrinsic association parameter $\varnothing$ is allowed to vary with layers. The model fitness is satisfactory and this model is used as the baseline model in Table 4.

[Table 4 about Here] 
Model M2 is firstly used to identify changes in levels of educational homogamy for each education group. In Model M2, one unique diagonal parameter is specified for each educational level and there are five parameters for each layer in total, which can vary freely across the seven layers. The 35 estimated homogamy odds ratios are summarized in Table 5. The greatest changes are among couples with associate qualification. The odds of marrying within-group rather than out-group for couples with associate qualification consistently decreased from 9.03 in 1981 to 1.22 only in 2011. However, the odds of homogamy vs. the odds of intermarriage for couples with university qualification fluctuate but the magnitude is limited. The increase in homogamy among degree holders during 1981 to 1991 seems to echo the status attainment hypothesis, when higher education became a more important means to attain high social positions. The later fluctuation and leveling off trend in homogamy for university graduates is likely to reveal the process of reconstruction and reinforcement of the group boundary. For those with primary or less levels of education, the odds of homogamy vs. the odds of intermarriage decreased over time from 6.17 to 3.39 , or by 45 percent. The declining trend in homogamy for people with primary or less levels of education is easy to understand, as people in this category have higher chances to marry up. For the group with associate qualification who seem to experience the most drastic increase in out-group marriage, a legitimate question is to whom they marry over time.

[Table 5 about Here]

In the remaining models in Table 4, I focus on changes in the educational intermarriage pattern by adding an additional dimension into the row and column interaction. In Model M3, only the joint associations $\left(\emptyset_{1 k}\right.$ and $\emptyset_{2 k}$ in Equation 3$)$ are allowed to change across layers. The model fitness has been greatly improved. To further simplify Model M3, in Model M4, I keep the first-dimensional intrinsic association $\left(\varnothing_{1 k}\right.$ in Equation 3$)$ constant over time and only the second-dimensional intrinsic association $\left(\varnothing_{2 k}\right.$ in Equation 3) varying across the seven years of census. Results from Table 3 have shown that the symmetrical row and column interactions are 
the most prominent time-varying structure. I thereby further constrain the scores of wife's and husband's education ( $\sigma_{i 2}$ and $\vartheta_{j 2}$ in Equation 3 ) to be the same in the second dimension in Model M4 (Clogg 1982). In this model specification, the first dimension denotes the time-invariant educational intermarriage structure, and the second dimension represents the educational intermarriage pattern with a symmetrical feature that changes over time. Model M4 is the best fitted model. Estimated scores for wife's and husband's education from Model M4 are plotted in Figure 3. More detailed information about the estimated scores and intrinsic parameters is available in Appendix A.

[Figure 3 about Here]

In Figure 3, the estimated scores from the first dimension are plotted along the horizontal axis and estimated scores from the second dimension are plotted along the vertical axis. The first dimension represents the persistent rankings of educational levels. The ranking of the estimated scores is consistent with the setup of the educational system in Hong Kong, and educational credentials are valued similarly for both women and men in the marriage market. Basically, the first-dimensional scores divide people into three education groups: the "less educated" group with lower secondary and less education, the "intermediate" group with upper secondary level of education, and the "more educated" group with post-secondary qualifications.

The second dimension represents the educational intermarriage structure that has substantially changed over time. Generally, the relative positions of the upper secondary and university qualifications do not departure much from the first dimension. Scores of the "less educated" group and the associate qualification are of higher absolute values along the vertical axis and are of opposite signs. Based on Equation 3, by referring to the product of the second-dimensional scores of the "less educated" group, the associate qualification, and the intrinsic association parameters (estimated values of $\emptyset_{2 k}$ are all negative), a positive product 
outcome means an increase in expected marriage frequency. Therefore, besides the time-constant educational intermarriage pattern represented by the first dimension, there are extensive exchanges between the group with associate qualification and the "less educated" group.

It should be also noted that, the absolute values of the second-dimensional intrinsic associations $\left(\varnothing_{2 k}\right.$ in Equation 3) increased consistently from 0.015 in 1981 to 2.621 in 2011 (Appendix A). In other words, the association between the "less educated" group and people with associate qualification is becoming stronger over time, everything else being equal. With the fast expansion of higher education, the huge decline in levels of homogamy for people with associate qualification is mostly a result of the increased intermarriage with the "less educated" group.

\section{Trends in Educational Assortative Mating by Immigration Status}

Besides the drastic improvement in education in Hong Kong, changes in immigration types and the rise of cross-border marriages is another factor contributing to changes in educational assortative mating. The decline of the illegal immigration since the mid-1980s and the increase in cross-border marriages thereafter have brought in continuous and stable influx of mainland born spouses, especially mainland Chinese women. It is therefore necessary to evaluate the trends in assortative mating from the perspective of changes in the composition of immigrants.

Based on the wife's birthplace, trends in educational assortative mating for couples of wives born in Hong Kong and those of wives from mainland China are presented. ${ }^{8}$ The additional layer of wife's birthplace creates a four-way table, which is presented in Appendix B. The relative proportions of homogamy, hypergamy, and hypogamy for the two groups over time are plotted in Figure 4. The dotted lines represent trends of mainland wives and the solid lines represent trends of Hong Kong wives. Clearly, trends in educational assortative mating differ by the two groups. The change is relatively negligible for couples of Hong Kong-born wives. For couples of 
immigrant wives, there was a clear decline in levels of homogamy and levels of hypogamy increased from five percent in 1981 to almost 25 percent in 2011. In 1981, around 70 percent of mainland wives married to someone with the same educational level, but it dropped to 50 percent in 2011. Given the huge educational gap between women born in Hong Kong and those from mainland China, the log-linear model is again used to control for the differences in marginal distributions between the two groups over time.

[Figure 4 about Here]

I simply employ the UNIDIFF model (Equation 1) to see changes in the overall educational assortative mating of the two groups. The BIC value is $-1,046$, with 195 degrees of freedom. The resulting estimates of the scale factors and their quasi-confidence intervals are plotted in Figure 5, revealing some interesting features of the trends in educational homogamy in Hong Kong.

[Figure 5 about Here]

As shown in Figure 5, the change in the scale factor is modest from 1 in 1981 to 0.86 in 2011 for couples with wives born in Hong Kong. The major change in levels of association is in fact among couples of immigrant wives, It declined consistently from 1.1 in 1981 to 0.73 in 2011. Before 1991, there is almost no difference between the two groups of couples. However, the association between wife's and husband's education for those with mainland-born wives is significantly weaker than that for couples with local wives after 1991, and such gap continues to be enlarging over time.

The much steeper decline in levels of educational assortative mating for couples of immigrant wives has shown a feature of negative assortative mating, which is usually a result of status exchange in the marriage market. The much more restricted immigration policy since the 1980s cut down the number of unauthorized immigrants and later immigrants could only come as the spouse or children of Hong Kong residents through the "one-way permit" system. Following 
this change, the surging numbers of "cross-border marriages" offers an opportunity for women from mainland China to exchange their relative advantage in one domain for the Hong Kong residence status by marrying men in Hong Kong, and education can be one resource that those women may be able to offer. Further analysis of couples with immigrant wives (not presented here) shows that immigrant wives of associate qualifications are increasingly likely to marry men in the "less educated" group, a finding consistent with the previous analysis of the trends in educational assortative mating by educational level based on the full sample. Hence, the increase in the proportion of cross-border marriages is an important factor contributing to the declining levels of educational assortative mating.

\section{Conclusion and Discussion}

This article examines the trends in educational assortative mating of the prevailing marriages from the sample data of seven censuses/by-censuses in Hong Kong during 1981 to 2011. During this period, educational homogamy dominates the marriage pattern in Hong Kong and the assortative mating pattern is in line with the setup of the educational system. People who are more distant in the education hierarchy are less likely to marry each other. Despite the stability of this marriage pattern in Hong Kong, an overall declined tendency in educational assortative mating is observed, which seems to echo the general openness theory. However, such a general trend provides only a partial account of changes in educational assortative mating in Hong Kong. Results from the RC model specifications show that the general decline is in fact dominated by the increased level of out-marriage among those with associate qualification, who are increasingly likely to marry downwards to those with lower secondary or less levels of education. Meanwhile, trends in levels of homogamy for university graduates fluctuated, and the level in 2011 was even much higher than that in 1981. 
The expansion of higher education and trends in economic inequality across the education groups may offer some insights. From the early 1990s on, Hong Kong has completed its industrial restructuring and the labor market shift from manufacturing to service jobs. The income gap between the rich and the poor was also widened in the 1990s (Wu 2007). The expansion of tertiary education in the meantime ensures a sufficient supply of highly educated labors for high-earning professional jobs and the increased wage gap implies the increased inequality between education groups (Lee et al. 2004, p 41). Associate qualification may experience great depreciation in the labor market and such depreciation of associate qualification can also be reflected in the marriage market. As a result, the numbers of out-group marriage to the less educated groups for people with associate qualification is surging.

Nevertheless, the depreciation of specific educational qualification in marriage market due to the educational expansion may be overestimated without considering the increase in cross-border marriages. Compared to couples of local wives, those of immigrant wives experienced a much more drastic decline in educational assortative mating since the late 1980s. This pattern can be accounted for by the exchange theory. If more immigrant wives exchange education for the Hong Kong permanent residency by marrying less educated spouses in Hong Kong when the border control is more restricted, we would observe ae more negative assortative mating pattern among couples with immigrant wives compared to those with local wives. Therefore, the huge increase in hypogamy for people with associate qualification should be partly attributed to increased cross-border marriages of immigrant wives with associate qualification marrying much less educated men in Hong Kong.

Research has shown that immigrant women are much less likely to be employed than their native counterparts (Zhang and Wu 2011). Some scholars argue that the disadvantages faced by low-skilled new immigrants and their families were major factors contributing to the rising income inequality in Hong Kong (e.g. Lam and Liu 1998; Lui 1997; Ou 2015; Post, Pong and Ou 
2014). Despite being relatively better educated than their husbands, when those women are with husbands of low socioeconomic status in Hong Kong and remain economically inactive, those immigrant families would be particularly disadvantaged, trapped in unemployment and poverty and have substantial impact on the educational outcome of their children (Zhang 2014). The negative assortative mating in cross-border marriages deserves more thorough studies if the information on the year in which the permanent residency was acquired, and on the year of marriage is available. Due to the lack of information on marriage timing, I can only document trends for prevailing marriages in Hong Kong from 1981 to 2011. This approach makes it difficult to pinpoint the effects of specific historical changes on marriage preference because members of various marriage cohorts selected their spouses under different economic conditions (Schwartz and Mare 2005). In addition, trends of prevailing marriages tend to lag those for the newlyweds. An increase in educational homogamy among people with university qualification has been noted in recent years. Stabilized or even increased homogamy among those highly educated is likely to bring in subsequent enlarged income inequality (e.g. Breen 2011; Greenwood et al. 2014). As a place experiencing high income inequality since the 1970s, should educational homogamy of the university educated group retain its strength, Hong Kong is likely to continue such huge household income gaps. 


\section{Endnotes}

1. The definition of cross-border marriages is based on the wife's and husband's residence status at the time of marriage rather than their birthplaces. It is common to see both spouses were born in mainland China, but one (usually the broom) is a Hong Kong permanent resident while the other is a mainland-Chinese resident at the time of marriage.

2. The number of cross-border marriage is based on the number of registered cross-border marriages in Hong Kong plus half of the number of issued certificates of absence of marriage record (CAMR) for each year.

3. Because the census/by-census data contain no information on marriage timing, I only focus on prevailing marriages in population from 1981 to 2011. It should be noted that there is a great overlap of population across the census data and the trends of the prevailing marriages represent all married couples at a given time. The selection issue that only married population are observed is not serious, as there are only about two percent to four percent of the people aged 60 or above who have never been married during this period. The proportion of those divorced or separated is only around five percent in 2011 among all population aged 21 to 60 and the proportion of those who were remarried only account for around 3 percent of all married population in 2011(Yip et al. 2014). Therefore, the bias brought by selective marital dissolution and remarriage should be not be serious.

4. Data used are the one percent random samples of the 1981 and 1986 population censuses or by-censuses, and the five percent random samples of the 1991, 1996, 2001, 2006, and 2011 population censuses or by-censuses. Due to the much smaller sample sizes in 1981 and 1986, the quasi-confidence intervals of the estimates scale factors for these two years are much wider than that of the rest.

5. Quasi-symmetry design matrix (main diagonal blocked): 


$\begin{array}{lllll}0 & 1 & 2 & 3 & 4 \\ 1 & 0 & 5 & 6 & 7 \\ 2 & 5 & 0 & 8 & 9 \\ 3 & 6 & 8 & 0 & 10 \\ & & & & \\ 4 & 7 & 9 & 10 & 0\end{array}$

6. Wife's hypergamy design matrix:

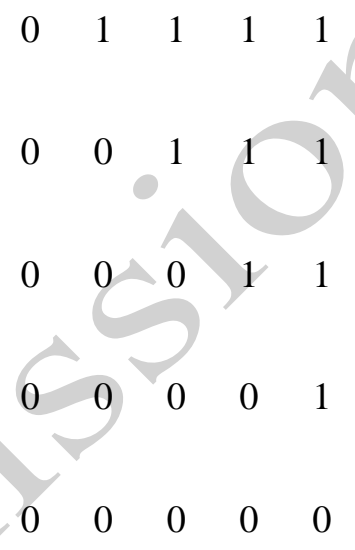

7. Parameters for the main diagonal cells are also set to be time-varying in Models 3 and 4.

8. Couples with wives born in places other than Hong Kong and mainland China are too heterogeneous and occupy less than seven percent of the total population. Those couples are not included. 


\section{About the Author}

Muzhi Zhou is a PhD student in the Department of Sociology at the University of Oxford. She is also affiliated with St Antony's College. Her areas of interest are family and marriage, social demography, and quantitative methodology; email: muzhi.zhou@sant.ox.ac.uk. 


\section{References}

Alba, Richard D., and Reid M. Golden. 1986. "Patterns of Ethnic Marriage in the United States." Social Forces 65(1):202-23.

Albertini, Marco. 2008. "Equalizing or Not? The Effect of Changing Household Characteristics on Income Inequality." European Sociological Review 24(3):285-98.

Blossfeld, Hans-Peter. 2009. "Educational Assortative Marriage in Comparative Perspective." Annual Review of Sociology 35:513-30.

Bourdieu, Pierre. 1977. "Cultural Reproduction and Social Reproduction." Pp. 487-511 in Power and Ideology in Education, edited by Jerome Karabel and A. H. Halsey. New York: Oxford University Press.

Breen, Richard. 2011. "Educational Assortative Mating and Earnings Inequality in the United States." American Journal of Sociology 117(3):808-43.

Census and Statistics Department, Hong Kong. 2012. "Women and Men in Hong Kong." in Key Statistics 2012 Edition. Hong Kong: General Household Survey Section (1) and Census and Statistics Department.

Chua, Hoi-wai, AnthonyK W. Wong, and DanielT L. Shek. 2010. "Social Development in Hong Kong: Development Issues Identified by Social Development Index (SDI)." Social Indicators Research 95(3):535-51.

Clogg, Clifford C. 1982. "Some Models for the Analysis of Association in Multiway Cross-Classifications Having Ordered Categories." Journal of the American Statistical Association 77(380):803-15.

Davis, Kingsley. 1941. "Intermarriage in Caste Societies." American Anthropologist 43(3):376-95.

Greenwood, Jeremy, Nezih Guner, Georgi Kocharkov, and Cezar Santos. 2014. "Marry Your Like: Assortative Mating and Income Inequality." American Economic Review 104(5):348-53.

Gullickson, Aaron, and Florencia Torche. 2014. "Patterns of Racial and Educational Assortative Mating in Brazil." Demography 51(3):835-56.

Halpin, Brendan, and Tak Wing Chan. 2003. "Educational homogamy in Ireland and Britain: trends and patterns." The British Journal of Sociology 54(4):473-95.

Han, Hongyun. 2010. "Trends in Educational Assortative Marriage in China from 1970 to 2000." Demographic Research 22(24):733-70.

Kalmijn, Matthijs. 1991a. "Shifting Boundaries: Trends in Religious and Educational Homogamy." American Sociological Review 56(6):786-800.

—. 1991b. "Status Homogamy in the United States." American Journal of Sociology 97(2):496-523.

—. 1998. "Intermarriage and Homogamy: Causes, Patterns, Trends." Annual Review of Sociology 24:395-421.

Kalmijn, Matthijs, and Henk Flap. 2001. "Assortative Meeting and Mating: Unintended Consequences of Organized Settings for Partner Choices." Social Forces 79(4):1289-312. 
Katrnák, Tomáš, Martin Kreidl, and Laura Fónadová. 2006. "Trends in Educational Assortative Mating in Central Europe: the Czech Republic, Slovakia, Poland, and Hungary, 1988-2000." European Sociological Review 22(3):309-22.

Lam, Kit-Chun, and Pak-Wai Liu. 1998. "Immigration, Population Heterogeneity, and Earnings Inequality In Hong Kong." Contemporary Economic Policy 16(3):265-76.

Lee, William, Jorge A. Chan-Lau, Dora M. Iakova, Papa M'B. P. N'Diaye, Tao Wang, Ida Liu, Hong Liang, and Eswar Prasad. 2004. Hong Kong SAR: Meeting the Challenges of Integration with the Mainland: International Monetary Fund.

Lin, Ge, and Zhongdong Ma. 2008. "Examining Cross-border Marriages in Hong Kong Since Its Return to China in 1997." Population, Space and Place 14:407-18.

Liu, Pak-Wai, and Junsen Zhang. 1999. "Assortative mating versus the cross-productivity effect." Applied Economics Letters 6(8):523-25.

Lui, Hon-kwong. 1997. Income inequality and economic development: City University of Hong Kong Press.

Mare, Robert D. 1991. "Five Decades of Educational Assortative Mating." American Sociological Review 56(1):15-32.

Merton, Robert K. 1941. "Intermarriage and the Social Structure." Psychiatry 4(3):361-74.

Oppenheimer, VK. 1988. "A theory of marriage timing." American Journal of Sociology 94(3):563-91.

Ou, Dongshu. 2015. "Immigrants and earnings inequality across gender: evidence from Hong Kong." Journal of Asian Public Policy:1-31.

Park, Hyunjoon, and Jeroen Smits. 2005. "Educational Assortative Mating in South Korea: Trends 1930-1998." Research in social stratification and mobility 23(0):103-27.

Pong, Suet-ling, David Post, Dongshu Ou, and Maggie S. Y. Fok. 2014. "Blurring Boundaries? Immigration and Exogamous Marriages in Hong Kong." Population and Development Review 40(4):629-52.

Post, David. 1994. "Educational Stratification, School Expansion, and Public Policy in Hong Kong." Sociology of Education 67(2):121-38.

Post, David, Suet-ling Pong, and Dongshu Ou. 2014. "One Country Two Peoples?" Asian Population Studies 11(1):67-93.

Qian, Zhenchao, and Daniel T. Lichter. 2001. "Measuring Marital Assimilation: Intermarriage among Natives and Immigrants." Social Science Research 30(2):289-312.

Raftery, Adrian. 1995. "Bayesian Model Selection in Social Research." Sociological Methodology 25:111-63.

Raymo, James M., and Yu Xie. 2000. "Temporal and Regional Variation in the Strength of Educational Homogamy." American Sociological Review 65(5):773-81.

Rosenfeld, Michael J. 2008. "Racial, Educational, and Religious Endogamy In the United States: A Comparative Historical Perspective." Social Forces 87(1):1-31.

Rytina, Steven, Peter M. Blau, Terry Blum, and Joseph Schwartz. 1988. "Inequality and Intermarriage: A Paradox of Motive and Constraint." Social Forces 66(3):645-75.

Schwartz, Christine R. 2010. "Earnings Inequality and the Changing Association between Spouses' Earnings." American Journal of Sociology 115(5):1524-57.

—. 2013. "Trends and Variation in Assortative Mating: Causes and Consequences." Annual Review of Sociology 39:451-70.

Schwartz, Christine R., and Robert D. Mare. 2005. "Trends in educational assortative marriage from 1940 to 2003." Demography 42(4):621-46. 
Smits, Jeroen. 2003. "Social closure among the higher educated: trends in educational homogamy in 55 countries." Social Science Research 32(2):253-77.

Smits, Jeroen, and Hyunjoon Park. 2009. "Five Decades of Educational Assortative Mating in 10 East Asian Societies." Social Forces $88(1): 227-55$.

Smits, Jeroen, Wout Ultee, and Jan Lammers. 1998. "Educational Homogamy in 65 Countries: An Explanation of Differences in Openness Using Country-Level Explanatory Variables." American Sociological Review 63(2):264-85.

- 2000. "More or less educational homogamy? A test of different versions of modernization theory using cross-temporal evidence for 60 countries." American Sociological Review 65:781-88.

So, Alvin Y. 2003. "Cross-border families in Hong Kong - The role of social class and politics." Critical Asian Studies 35(4):515-34.

Torche, Florencia. 2010. "Educational assortative mating and economic inequality: A comparative analysis of three Latin American countries." Demography 47(2):481-52.

Wong, Raymond Sin-Kwok. 2010. Association Models. Los Angeles ; London: SAGE

Wu, Xiaogang. 2007. "Family Resources and Educational Stratification: The Case of Hong Kong, 1981-2001." Social Transformations in Chinese Societies 3:173-201.

—. 2009. "Income Inequality and Distributive Justice: A Comparative Analysis of Mainland China and Hong Kong." The China Quarterly 200(Fall):1033-52.

Xie, Yu. 1992. "The Log-Multiplicative Layer Effect Model for Comparing Mobility Tables." American Sociological Review 57(3):380-95.

Xu, Qi, Jianxin Li, and Xuejun Yu. 2014. "Continuity and Change in Chinese Marriage and the Family." Chinese Sociological Review 47(1):30-56.

Yip, Paul, Shu-sen Chang, Frances Law, Lianne Tai, Sandra Tang, and Melissa Chan. 2014. "A study on the phenomenon of divorce in Hong Kong." Hong Kong: Centre for Suicide Research and Prevention, The University of Hong Kong.

Zhang, Zhuoni. 2014. "Contingent Transition to Triumph." Chinese Sociological Review 46(4):68-88.

Zhang, Zhuoni, and Xiaogang Wu. 2011. "Social Changes, Cohort Quality, and Economic Adaptation of Chinese Immigrants in Hong Kong, 1991-2006." Asian and Pacific Migration Journal 20:1-29. 
Table 1

Summary Statistics for Married Women Aged 21 to 60 and Their Husbands in Hong Kong from 1981 to 2011

\begin{tabular}{|c|c|c|c|c|c|c|c|c|c|c|c|c|c|c|}
\hline & \multicolumn{2}{|c|}{$1981(1 \%)$} & \multicolumn{2}{|c|}{$1986(1 \%)$} & \multicolumn{2}{|c|}{$1991(5 \%)$} & \multicolumn{2}{|c|}{$1996(5 \%)$} & \multicolumn{2}{|c|}{$2001(5 \%)$} & \multicolumn{2}{|c|}{$2006(5 \%)$} & \multicolumn{2}{|c|}{$2011(5 \%)$} \\
\hline & Women & Men & Women & Men & Women & Men & Women & Men & Women & Men & Women & Men & Women & Men \\
\hline Age (mean) & 39 & 44 & 39 & 44 & 39 & 43 & 40 & 44 & 42 & 46 & 44 & 48 & 45 & 49 \\
\hline Age (Hong Kong born) (mean) & 33 & 37 & 34 & 37 & 36 & 38 & 38 & 40 & 40 & 43 & 43 & 45 & 45 & 47 \\
\hline Age (Mainland born) (mean) & 43 & 46 & 43 & 47 & 43 & 48 & 43 & 49 & 44 & 51 & 44 & 52 & 45 & 52 \\
\hline \multicolumn{15}{|l|}{ Birth Place $(\%)$} \\
\hline Hong Kong & 38.2 & 28.6 & 45.7 & 36.9 & 50.7 & 43.6 & 53.9 & 49.6 & 54.2 & 52.5 & 55.4 & 57.6 & 56.7 & 62.1 \\
\hline Mainland & 56.4 & 66.7 & 47.5 & 57.0 & 41.8 & 49.8 & 38.1 & 43.8 & 37.9 & 41.4 & 37.8 & 37.3 & 37.0 & 32.7 \\
\hline Others & 5.4 & 4.7 & 6.8 & 6.1 & 7.6 & 6.6 & 8.0 & 6.6 & 7.9 & 6.2 & 6.8 & 5.1 & 6.3 & 5.2 \\
\hline \multicolumn{15}{|l|}{ Education (\%) } \\
\hline Primary or Less & 66.2 & 53.5 & 56.5 & 44.7 & 45.8 & 37.2 & 36.0 & 29.6 & 32.1 & 27.9 & 26.4 & 23.8 & 20.9 & 20.3 \\
\hline Lower Secondary & 12.9 & 17.3 & 16.3 & 19.2 & 19.6 & 22.8 & 21.1 & 24.2 & 21.6 & 24.5 & 22.2 & 24.6 & 21.6 & 23.2 \\
\hline Upper Secondary & 17.3 & 21.0 & 21.6 & 25.7 & 24.6 & 24.2 & 29.9 & 26.6 & 31.5 & 27.2 & 32.5 & 27.9 & 30.6 & 26.1 \\
\hline Associate & 1.1 & 2.1 & 2.5 & 2.7 & 6.4 & 7.8 & 6.2 & 7.7 & 6.7 & 7.7 & 8.0 & 8.6 & 11.8 & 11.6 \\
\hline University & 2.6 & 6.2 & 3.1 & 7.7 & 3.6 & 8.0 & 6.7 & 11.9 & 8.1 & 12.7 & 11.0 & 15.2 & 15.1 & 18.8 \\
\hline \multicolumn{15}{|l|}{ Education (Hong Kong born) (\%) } \\
\hline Primary or Less & 56.5 & 39.8 & 47.8 & 32.4 & 37.2 & 26.5 & 29.2 & 21.4 & 24.8 & 19.3 & 20.4 & 16.8 & 16.4 & 14.8 \\
\hline Lower Secondary & 16.9 & 20.6 & 17.6 & 20.9 & 19.5 & 22.8 & 19.1 & 22.6 & 17.7 & 21.9 & 16.8 & 21.7 & 13.4 & 19.6 \\
\hline Upper Secondary & 24.1 & 29.8 & 29.0 & 34.5 & 33.0 & 31.8 & 37.8 & 32.5 & 40.3 & 33.5 & 39.3 & 32.3 & 38.2 & 30.2 \\
\hline Associate & 0.8 & 3.4 & 3.0 & 4.1 & 7.3 & 10.4 & 7.6 & 10.4 & 8.2 & 10.0 & 9.8 & 10.5 & 13.0 & 13.1 \\
\hline University & 1.6 & 6.5 & 2.7 & 8.0 & 2.9 & 8.5 & 6.3 & 13.2 & 9.0 & 15.5 & 13.7 & 18.7 & 19.0 & 22.4 \\
\hline \multicolumn{15}{|l|}{ Education (Mainland born)(\%) } \\
\hline Primary or Less & 75.5 & 61.8 & 67.1 & 54.7 & 58.3 & 48.9 & 47.1 & 41.2 & 43.2 & 40.5 & 35.0 & 35.4 & 32.1 & 28.2 \\
\hline Lower Secondary & 10.4 & 16.1 & 15.3 & 18.3 & 20.2 & 23.3 & 24.9 & 27.1 & 28.2 & 29.3 & 30.8 & 30.1 & 31.7 & 32.0 \\
\hline Upper Secondary & 11.3 & 16.5 & 13.5 & 20.0 & 14.9 & 17.8 & 20.3 & 20.5 & 20.6 & 19.8 & 23.9 & 21.7 & 19.8 & 22.5 \\
\hline Associate & 0.9 & 1.2 & 1.9 & 1.6 & 4.1 & 5.0 & 3.7 & 4.7 & 4.2 & 4.7 & 5.2 & 5.7 & 8.5 & 9.0 \\
\hline University & 2.0 & 4.4 & 2.3 & 5.3 & 2.5 & 5.0 & 4.1 & 6.6 & 3.8 & 5.7 & 5.0 & 7.1 & 7.9 & 8.4 \\
\hline Total Number of Couples & \multicolumn{2}{|c|}{7,263} & \multicolumn{2}{|c|}{8,757} & \multicolumn{2}{|c|}{49,219} & \multicolumn{2}{|c|}{58,232} & \multicolumn{2}{|c|}{61,636} & \multicolumn{2}{|c|}{63,557} & \multicolumn{2}{|c|}{65,527} \\
\hline
\end{tabular}


Table 2

Percentage Distribution of Wife's and Husband's Education (Wives 21-60), by Year: Hong Kong, 1981-2011

Wife

Huaband (\%)

\begin{tabular}{cccccc}
\hline $\begin{array}{c}\text { Primary or } \\
\text { Less }\end{array}$ & $\begin{array}{c}\text { Lower } \\
\text { Secondary }\end{array}$ & $\begin{array}{c}\text { Upper } \\
\text { Secondary }\end{array}$ & Associate & University & Total \\
\hline
\end{tabular}

\section{1}

Primary or Less $\quad 48.7$

Lower Secondary

$48.3-10.4$

Upper Secondary

3.7

10.4

6.8

$4.6 \quad 3.9$

0.2

0.5

66.2

Associate

1.4

2.2

9.7

0.3

0.4

12.9

University

0.0

0.0

0.2

1.0

3.0

17.3

Total

53.4

17.3

0.4

0.1

2.0

\section{6}

Primary or Less

Lower Secondary

Upper Secondary

$38.6 \quad 10.0$

21.0

2.1

2.0

2.5

University $\quad 0.1$

Total

44.7

$10.0 \quad 7.2$

5.2

0.3

6.2

100.0

\section{1}

Primary or Less $\quad 30$.

Lower Secondary 4.7

Upper Secondary

$30.0 \quad 9.7$

2.8

12.5

0.1

0.0

$\begin{array}{ll}0.1 & 0.1 \\ 0.0 & 0.0\end{array}$

Associate

4.7
2.2

19.2

0.7

0.2

25.7

0.3
0.2

0.4

0.7

2.9

56.5

16.3

1.4

1.0

21.6

0.1

$2.6 \quad 3.1$

University 0.0

Total

37.2

9.7
8.4

5.0

$2.7 \quad 7.7$

100.0

\section{6}

Primary or Less

Lower Secondary $\quad 5.0$

Upper Secondary 2.7

Associate

University

Total

$21.6 \quad 8.9$

4.2

0.5

0.1

22.8

5.0

5.0
12.5

\section{8}

1.0

$0.3 \quad 45.8$
0.5

0.2

1.4

3.2

0.5

19.6

0.3

2.5

2.5

24.6

$\begin{array}{lll}3.5 & 1.7 & 6.4 \\ 0.3 & 2.9 & 3.6\end{array}$

0.3

2.9

3.6

\section{1}

Primary or Less

Lower Secondary

Upper Secondary

Associate

$8.9-4.6$

4.6

0.6

8.0

University

Total

2.7
0.2

9.1

5.5

$5.6 \quad 14.5$

0.9

0.3

3.5

0.6

3.7

1.3

0.2

0.1

24.2

0.7

2.1

29.6

$24.2 \quad 26.6$

0.6

2.1

5.2

$11.9 \quad 100.0$

\section{6}

Lower Secondary 5.

Upper Secondary $\quad 3.0$

Associate

University

19.1

8.2

3.9

0.6

0.3

32.1

Total

$5.6 \quad 9.1$

6.3

5.5

0.9

0.5

21.6

$\begin{array}{ll}0.3 & 0.6\end{array}$

15.1

3.4

3.8

31.5

0.1

0.3

1.1

1.1

0.8

2.1

6.7

24.5

0.8

5.9

8.1

\section{1}

\begin{tabular}{lcccccc} 
Primary or Less & 11.4 & 5.7 & 2.8 & 0.8 & 0.2 & 20.9 \\
Lower Secondary & 5.3 & 9.3 & 5.0 & 1.4 & 0.5 & 21.6 \\
Upper Secondary & 2.8 & 6.4 & 13.6 & 4.2 & 3.6 & 30.6 \\
Associate & 0.7 & 1.3 & 3.0 & 3.3 & 3.5 & 11.8 \\
University & 0.2 & 0.5 & 1.7 & 1.8 & 10.9 & 15.1 \\
\hline Total & 20.3 & 23.2 & 26.1 & 11.6 & 18.7 & 100.0 \\
\hline
\end{tabular}


Table 3

Statistics of Log-Linear Models of the Association between Wife's and Husband's Education (Wives Aged 20-61): Hong Kong, 1981-2011

Model

\begin{tabular}{|c|c|c|c|c|c|}
\hline Number & Model Description & $d f$ & $L^{2}$ & $B I C$ & $P$ \\
\hline 1 & Homogeneous full-interaction ${ }^{a}$ & 96 & 1,230 & 15 & 0.000 \\
\hline 2 & Full log-multiplicative layer effect & 90 & 546 & & 0.000 \\
\hline 3 & $\begin{array}{l}\text { Log-multiplicative layer effect for quasi-symmetry } \\
\text { specification }\end{array}$ & 84 & 490 & & 0.000 \\
\hline 4 & $\begin{array}{l}\text { Log-multiplicative layer effect for quasi-symmetry } \\
\& \text { hypergamy specifications }\end{array}$ & 78 & & 0 & 0.000 \\
\hline
\end{tabular}

Notes: For models with layer effects, they are all log-multiplicative layer effect models in which the specified structure does not change for each layer, only the strength of association changes with time.

${ }^{\mathrm{a}}$ Parameters for diagonals are estimated separately.

\begin{tabular}{|c|c|c|c|c|c|}
\hline $\begin{array}{l}\text { Model } \\
\text { Number }\end{array}$ & Model Description & $d f$ & $L^{2}$ & $B I C$ & $P$ \\
\hline M1 & Quasi RC(1)-Layer effect ${ }^{a}$ & 88 & 564 & -549 & 0.000 \\
\hline M2 & $\begin{array}{l}\text { Quasi RC(1)-Layer effect }{ }^{\mathrm{a}} \text { but diagonal changes } \\
\text { with layers heterogamously }\end{array}$ & 64 & 268 & -542 & 0.000 \\
\hline M3 & Quasi RC(2)-Layer effect ${ }^{a}$ on both dimensions & 75 & 226 & -724 & 0.000 \\
\hline M4 & $\begin{array}{l}\text { Quasi } \mathrm{RC}(2)^{\mathrm{b}} \text {-Layer effect }{ }^{\mathrm{a}} \text { on the } 2 \text { nd dimension } \\
\text { only }\end{array}$ & 84 & 280 & -783 & 0.000 \\
\hline
\end{tabular}

Notes: Parameters for diagonals are estimated separately for all models.

${ }^{a}$ Log-multiplicative layer effect for cells across the main diagonal in which the estimated scores does not change for each layer while the strength of association changes with time.

${ }^{\mathrm{b}}$ Symmetric parameter estimates for the row and column scores for $\mathrm{M}=2$ (2nd dimension), unrestricted for $\mathrm{M}=1$ (1st dimension) 
Table 5

Estimated Odds of Homogamy Parameters from Model M2 in Table 4

\begin{tabular}{lccccccc} 
& 1981 & 1986 & 1991 & 1996 & 2001 & 2006 & 2011 \\
\hline Primary or Less & 6.17 & 5.07 & 4.98 & 4.10 & 3.95 & 4.12 & 3.39 \\
Lower Secondary & 0.91 & 1.14 & 1.05 & 1.02 & 0.94 & 0.93 & 1.00 \\
Upper Secondary & 1.75 & 1.68 & 1.83 & 1.65 & 1.71 & 1.58 & 1.75 \\
Associate & 9.03 & 3.49 & 2.12 & 2.03 & 1.91 & 1.69 & 1.22 \\
University & 1.65 & 3.82 & 4.97 & 3.14 & 2.76 & 3.03 & 3.59 \\
\hline
\end{tabular}


Figure 1. Observed Proportions of Homogamy, Hypergamy and Hypogamy (Wives Aged 20-61): Hong Kong, 1981-2011

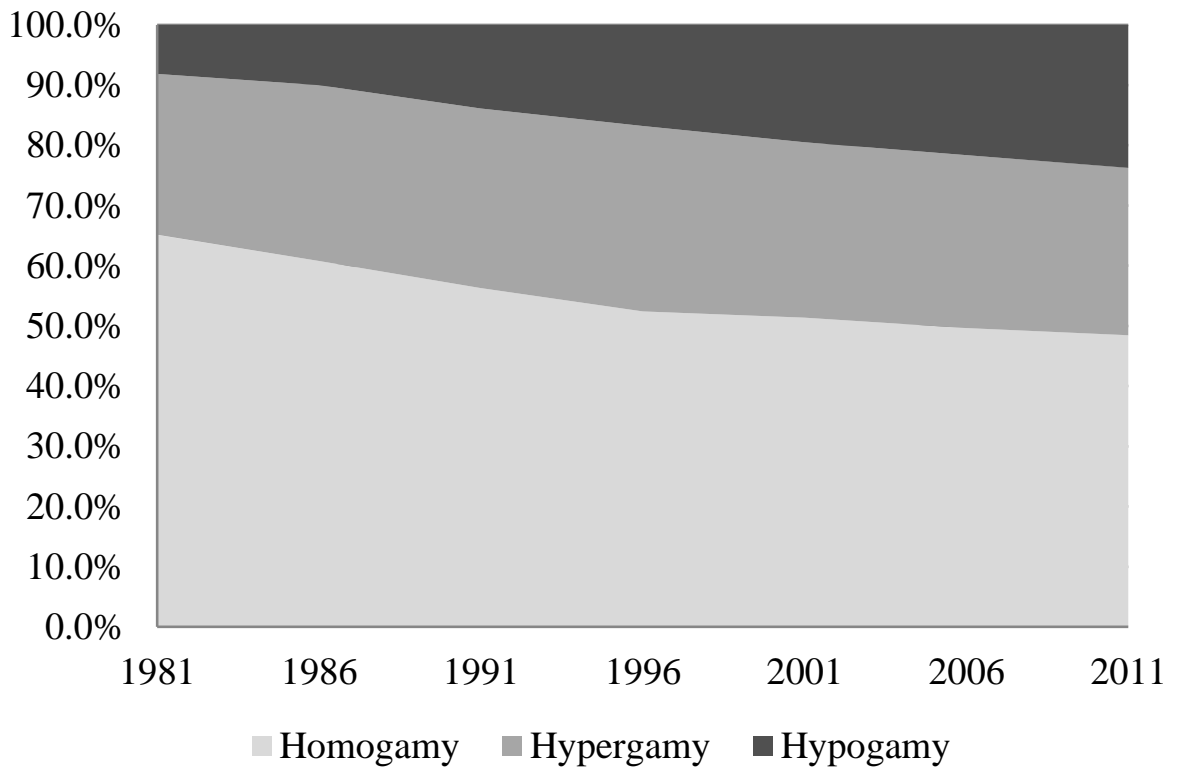

Figure 2. Estimates of the Log-Multiplicative Scale Factor $\varnothing$ and 95\% Quasi-Confidence Intervals of the Association between Wife's and Husband's Education from Model 2 in Table 3

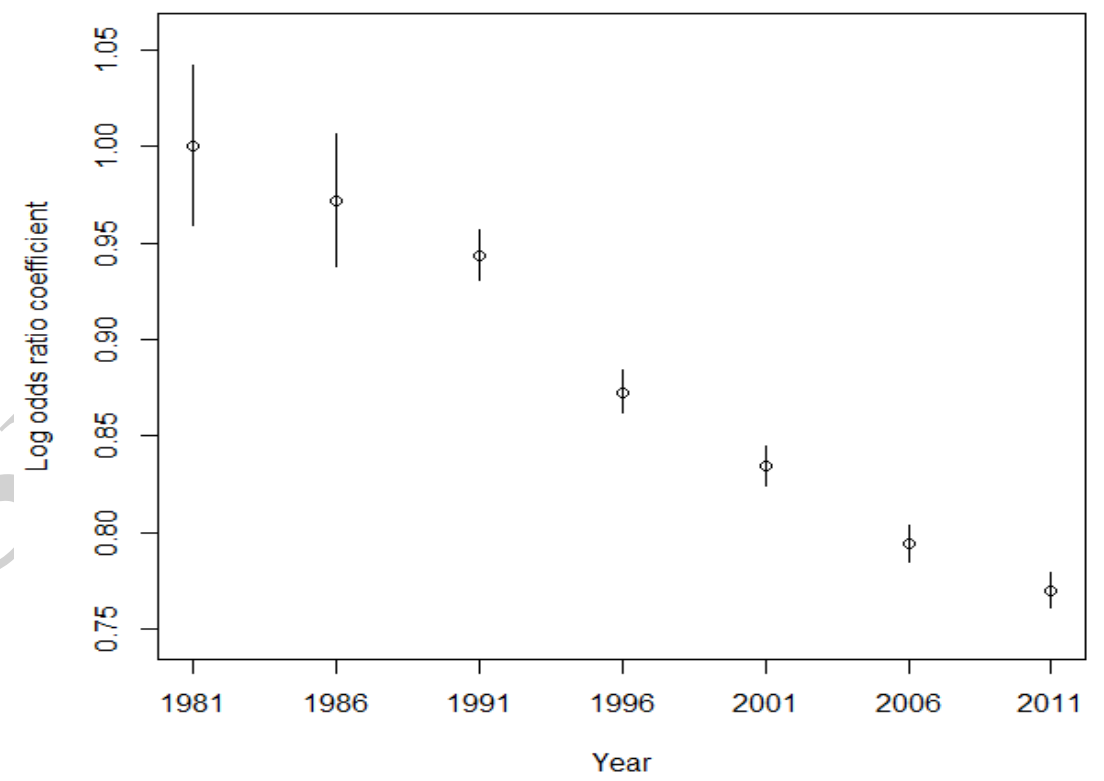


Figure 3. Estimated Scores of the Five Educational Levels for Wives and Husbands from Model M4 in Table 4

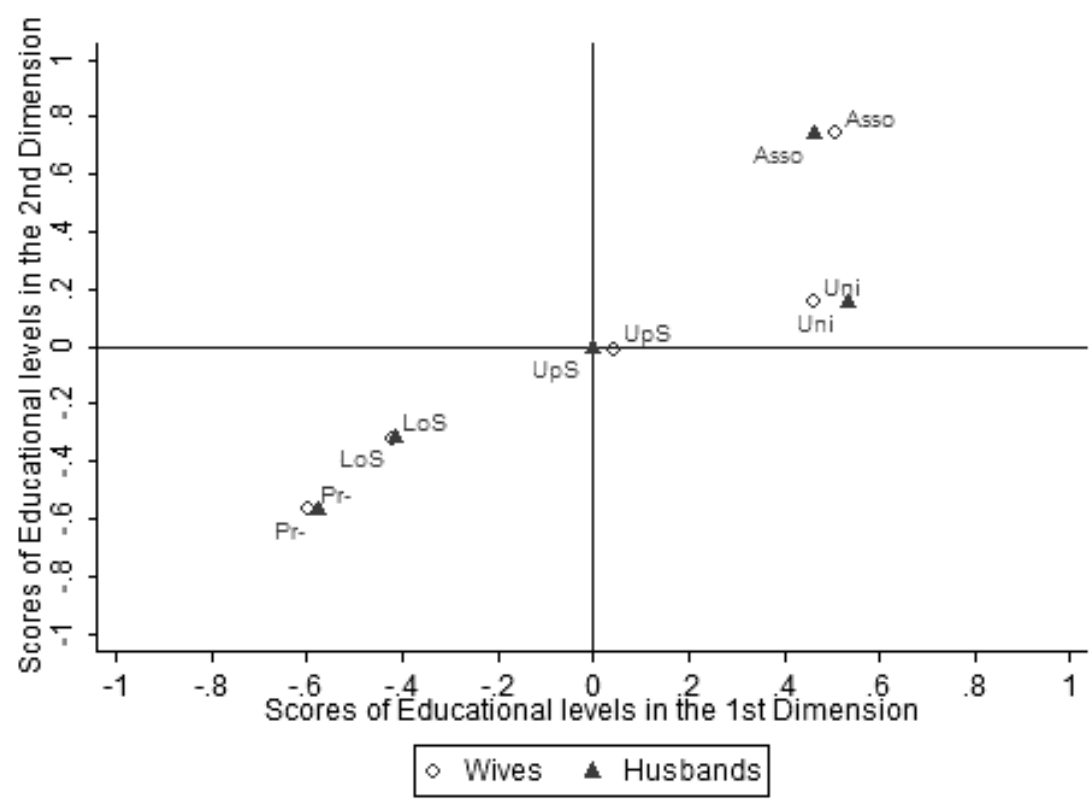

Figure 4. Observed Proportions of Homogamy, Hypergamy and Hypogamy (Wives Aged 20-61): by Wife's Birth Place

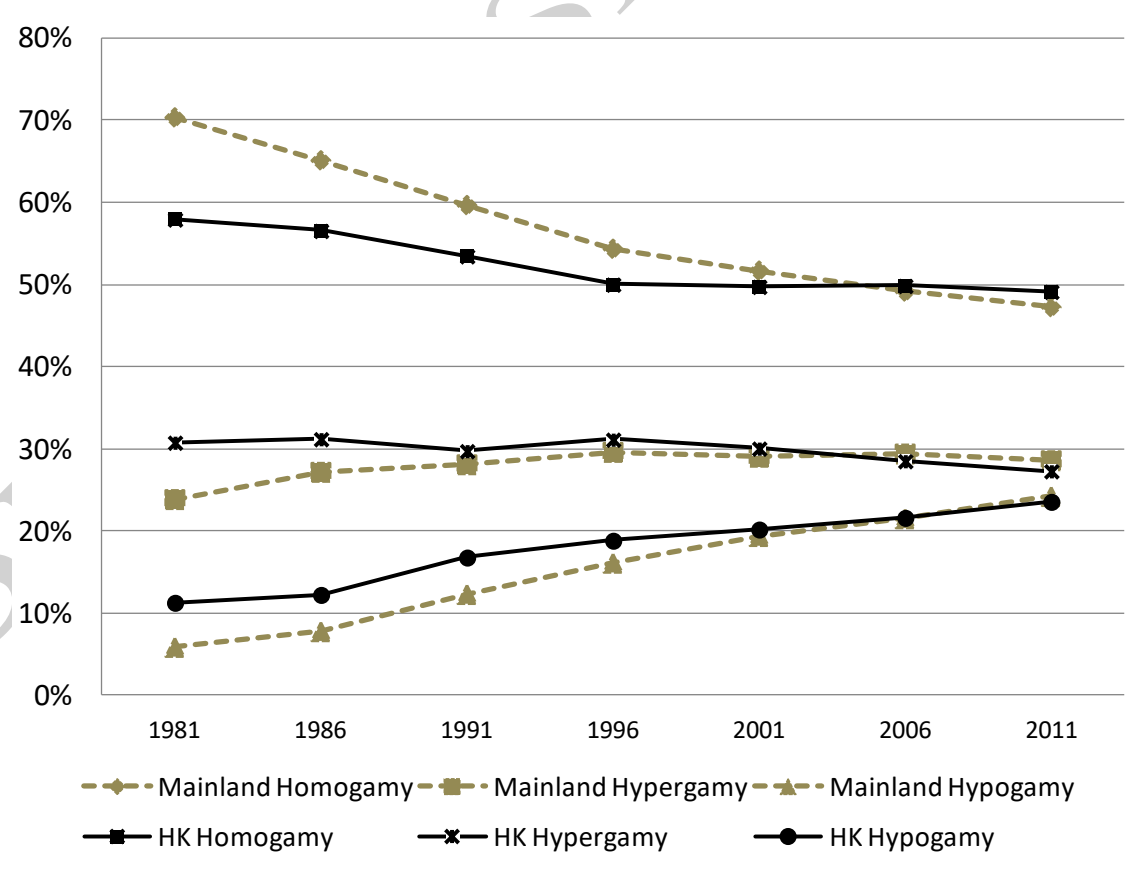


Figure 5. Estimates of the Log-Multiplicative Scale Factor and 95\% Quasi-Confidence Intervals from the UNIDIFF Model for Couples with Wives Born in Hong Kong and Mainland China

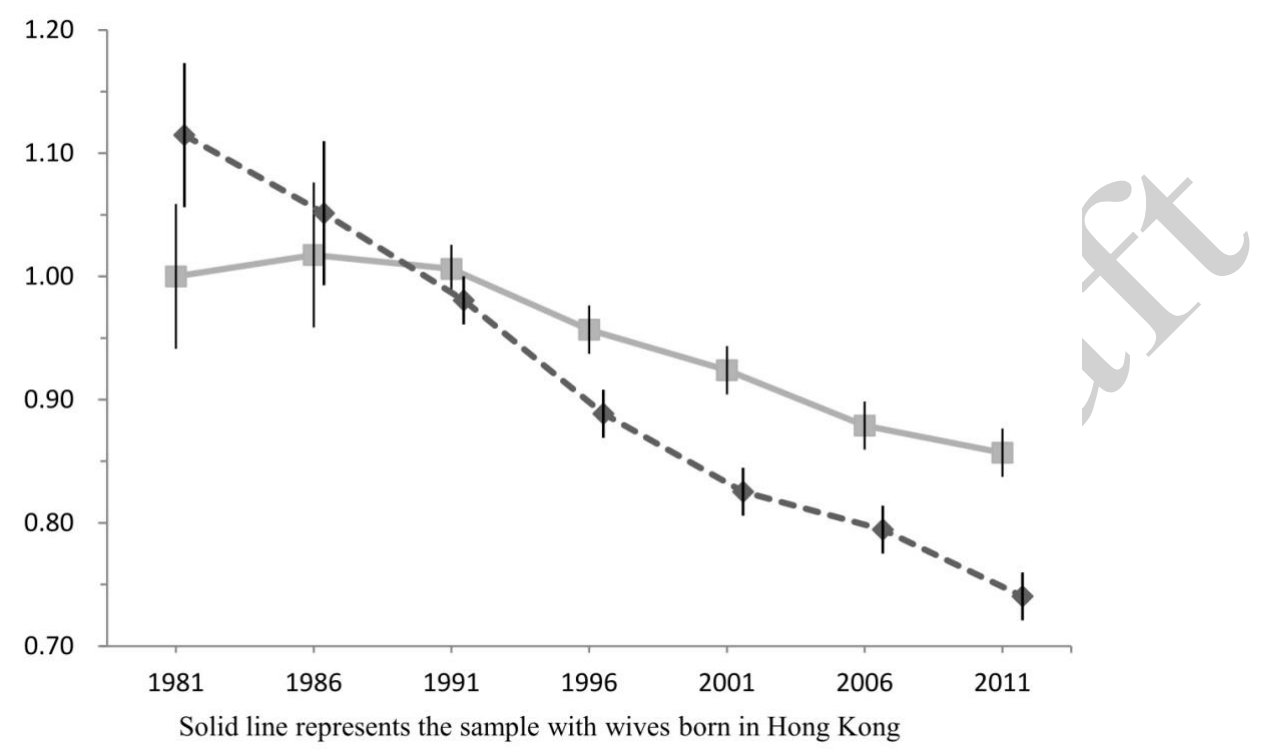


Appendix A

Estimated intrinsic association parameters and row and column scores from Model M4 in Table 4

\begin{tabular}{|c|c|c|c|}
\hline Parameters & & 1st Dimension & 2nd Dimension \\
\hline \multirow{7}{*}{$\begin{array}{l}\text { Intrinsic Association } \\
\qquad\left(\varnothing_{m k}\right)\end{array}$} & 1981 & 5.675 & -0.015 \\
\hline & 1986 & 5.675 & -1.141 \\
\hline & 1991 & 5.675 & -1.947 \\
\hline & 1996 & 5.675 & -1.802 \\
\hline & 2001 & 5.675 & -1.926 \\
\hline & 2006 & 5.675 & -2.207 \\
\hline & 2011 & 5.675 & -2.621 \\
\hline \multirow{5}{*}{$\begin{array}{l}\text { Scores of Wife's } \\
\text { education }\left(\sigma_{i m}\right)\end{array}$} & Primary- & -0.594 & -0.568 \\
\hline & Lower Secondary & -0.419 & -0.320 \\
\hline & Upper Secondary & 0.044 & -0.009 \\
\hline & Associate & 0.507 & 0.742 \\
\hline & University+ & 0.462 & 0.154 \\
\hline \multirow{5}{*}{$\begin{array}{l}\text { Scores of Husband's } \\
\text { education }\left(\vartheta_{j m}\right)\end{array}$} & Primary- & -0.578 & -0.568 \\
\hline & Lower Secondary & -0.413 & -0.320 \\
\hline & Upper Secondary & -0.003 & -0.009 \\
\hline & Associate & 0.462 & 0.742 \\
\hline & University+ & 0.531 & 0.154 \\
\hline
\end{tabular}


Appendix B

Percentage Distribution of Wife's and Husband's Educational Level in Prevailing Marriages, by Wife's Birth Place and Year (Wives 21-60): Hong Kong, 1981-2011

\begin{tabular}{|c|c|c|c|c|c|c|c|c|c|c|c|c|}
\hline \multirow[t]{2}{*}{ Wife } & \multicolumn{5}{|c|}{ Huaband (\%) } & \multirow[b]{2}{*}{ Total } & \multicolumn{5}{|c|}{ Huaband (\%) } & \multirow[b]{2}{*}{ Total } \\
\hline & $\begin{array}{c}\text { Primary or } \\
\text { Less }\end{array}$ & $\begin{array}{c}\text { Lower } \\
\text { Secondary }\end{array}$ & $\begin{array}{c}\text { Upper } \\
\text { Secondary }\end{array}$ & Associate & University & & $\begin{array}{c}\text { Primary or } \\
\text { Less }\end{array}$ & $\begin{array}{c}\text { Lower } \\
\text { Secondary }\end{array}$ & $\begin{array}{c}\text { Upper } \\
\text { Secondary }\end{array}$ & Associate & University & \\
\hline & \multicolumn{6}{|c|}{ Wife's birth place is Hong Kong } & \multicolumn{6}{|c|}{ Wife's birth place is mainland China } \\
\hline \multicolumn{13}{|c|}{ 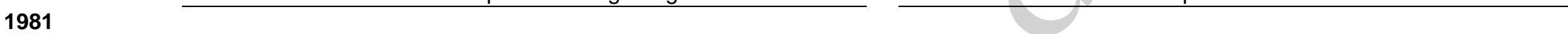 } \\
\hline Primary or Less & 36.7 & 11.9 & 7.3 & 0.3 & 0.4 & 56.5 & 58.4 & 9.8 & 6.7 & 0.1 & 0.5 & 75.5 \\
\hline Lower Secondary & 5.2 & 5.7 & 5.3 & 0.5 & 0.3 & 16.9 & 2.8 & 3.8 & 3.1 & 0.2 & 0.5 & 10.4 \\
\hline Upper Secondary & 1.7 & 3.7 & 13.9 & 1.6 & 3.1 & 24.1 & 1.1 & 1.3 & 6.2 & 0.4 & 2.2 & 11.3 \\
\hline Associate & 0.0 & 0.0 & 0.3 & 0.4 & 0.0 & 0.8 & 0.0 & 0.0 & 0.1 & 0.4 & 0.3 & 0.9 \\
\hline University & 0.0 & 0.0 & 0.2 & 0.1 & 1.3 & 1.6 & 0.0 & 0.1 & 0.3 & 0.1 & 1.5 & 2.0 \\
\hline Total & 43.6 & 21.4 & 27.0 & 2.9 & 5.1 & 100.0 & 62.4 & 15.0 & 16.4 & 1.3 & 5.0 & 100.0 \\
\hline \multicolumn{13}{|l|}{1986} \\
\hline Primary or Less & 29.5 & 10.5 & 7.1 & 0.3 & 0.3 & 47.8 & 48.9 & 10.1 & 7.5 & 0.3 & 0.4 & 67.1 \\
\hline Lower Secondary & 4.5 & 6.5 & 5.8 & 0.2 & 0.4 & 17.6 & 3.3 & 6.4 & 4.5 & 0.2 & 0.9 & 15.3 \\
\hline Upper Secondary & 2.5 & 3.8 & 17.4 & 2.1 & 3.1 & 29.0 & 1.7 & 1.7 & 7.5 & 0.7 & 1.9 & 13.5 \\
\hline Associate & 0.0 & 0.1 & 0.7 & 0.9 & 1.2 & 2.9 & 0.1 & 0.1 & 0.6 & 0.4 & 0.7 & 1.9 \\
\hline University & 0.0 & 0.0 & 0.2 & 0.2 & 2.3 & 2.7 & 0.0 & 0.0 & 0.2 & 0.0 & 1.9 & 2.3 \\
\hline Total & 36.6 & 21.0 & 31.3 & 3.8 & 7.3 & 100.0 & 54.0 & 18.3 & 20.3 & 1.6 & 5.8 & 100.0 \\
\hline \multicolumn{13}{|l|}{1991} \\
\hline Primary or Less & 22.4 & 9.2 & 4.7 & 0.6 & 0.2 & 37.2 & 40.5 & 10.8 & 5.6 & 1.0 & 0.4 & 58.3 \\
\hline Lower Secondary & 4.6 & 8.0 & 5.6 & 0.9 & 0.3 & 19.5 & 5.0 & 8.9 & 4.6 & 1.1 & 0.6 & 20.2 \\
\hline Upper Secondary & 2.7 & 5.6 & 17.0 & 4.9 & 3.0 & 33.0 & 1.9 & 2.6 & 7.4 & 1.4 & 1.6 & 14.9 \\
\hline Associate & 0.2 & 0.4 & 2.1 & 2.8 & 1.8 & 7.3 & 0.2 & 0.5 & 0.6 & 1.7 & 1.0 & 4.1 \\
\hline University & 0.0 & 0.0 & 0.2 & 0.3 & 2.3 & 2.9 & 0.1 & 0.1 & 0.2 & 0.2 & 2.0 & 2.5 \\
\hline Total & 29.9 & 23.3 & 29.6 & 9.5 & 7.7 & 100.0 & 47.7 & 22.9 & 18.3 & 5.4 & 5.6 & 100.0 \\
\hline
\end{tabular}


(Appendix B, continued)

\begin{tabular}{|c|c|c|c|c|c|c|c|c|c|c|c|c|}
\hline \multirow[t]{2}{*}{ Wife } & \multicolumn{5}{|c|}{ Huaband (\%) } & \multirow[b]{2}{*}{ Total } & \multicolumn{5}{|c|}{ Huaband (\%) } & \multirow[b]{2}{*}{ Total } \\
\hline & $\begin{array}{c}\text { Primary or } \\
\text { Less }\end{array}$ & $\begin{array}{c}\text { Lower } \\
\text { Secondary }\end{array}$ & $\begin{array}{c}\text { Upper } \\
\text { Secondary }\end{array}$ & Associate & University & & $\begin{array}{c}\text { Primary or } \\
\text { Less }\end{array}$ & $\begin{array}{c}\text { Lower } \\
\text { Secondary }\end{array}$ & $\begin{array}{c}\text { Upper } \\
\text { Secondary }\end{array}$ & Associate & University & \\
\hline & \multicolumn{6}{|c|}{ Wife's birth place is Hong Kong } & \multicolumn{6}{|c|}{ Wife's birth place is mainland China } \\
\hline \multicolumn{13}{|l|}{1996} \\
\hline Primary or Less & 16.5 & 7.8 & 4.1 & 0.5 & 0.2 & 29.2 & 29.9 & 10.7 & 5.3 & 0.8 & 0.4 & 47.1 \\
\hline Lower Secondary & 4.3 & 8.1 & 5.5 & 0.8 & 0.4 & 19.1 & 6.2 & 11.1 & 5.7 & 1.0 & 0.8 & 24.9 \\
\hline Upper Secondary & 2.9 & 6.9 & 18.7 & 5.0 & 4.4 & 37.8 & 2.6 & 4.1 & 9.4 & 1.8 & 2.3 & 20.3 \\
\hline Associate & 0.2 & 0.5 & 1.8 & 2.5 & 2.6 & 7.6 & 0.2 & 0.4 & 0.7 & 1.3 & 1.1 & 3.7 \\
\hline University & 0.0 & 0.1 & 0.7 & 0.7 & 4.7 & 6.3 & 0.1 & 0.2 & 0.5 & 0.3 & 3.0 & 4.1 \\
\hline \multicolumn{13}{|l|}{2001} \\
\hline Primary or Less & 14.0 & 6.5 & 3.5 & 0.5 & 0.2 & 24.8 & 26.8 & 10.8 & 4.5 & 0.8 & 0.3 & 43.2 \\
\hline Lower Secondary & 4.1 & 7.1 & 5.3 & 0.8 & 0.4 & 17.7 & 7.9 & 12.6 & 6.0 & 1.0 & 0.7 & 28.2 \\
\hline Upper Secondary & 2.8 & 7.6 & 20.2 & 4.8 & 4.9 & 40.3 & 2.9 & 5.2 & 9.0 & 1.7 & 1.9 & 20.6 \\
\hline Associate & 0.2 & 0.4 & 2.2 & 2.6 & 2.8 & 8.2 & 0.5 & 0.7 & 0.8 & 1.3 & 0.9 & 4.2 \\
\hline University & 0.1 & 0.2 & 1.2 & 1.0 & 6.5 & 9.0 & 0.1 & 0.2 & 0.6 & 0.3 & 2.6 & 3.8 \\
\hline Total & 21.2 & 21.9 & 32.4 & 9.7 & 14.8 & 100.0 & 38.2 & 29.5 & 20.9 & 5.1 & 6.4 & 100.0 \\
\hline \multicolumn{13}{|l|}{2006} \\
\hline Primary or Less & 11.2 & 5.4 & 3.1 & 0.5 & 0.2 & 20.4 & 20.8 & 9.0 & 4.3 & 0.7 & 0.2 & 35.0 \\
\hline Lower Secondary & 3.5 & 6.9 & 4.9 & 0.9 & 0.6 & 16.8 & 8.0 & 13.5 & 7.3 & 1.2 & 0.8 & 30.8 \\
\hline Upper Secondary & 2.7 & 7.9 & 19.0 & 4.7 & 5.0 & 39.3 & 3.4 & 6.3 & 10.1 & 2.0 & 2.2 & 23.9 \\
\hline Associate & 0.2 & 0.8 & 2.7 & 2.8 & 3.2 & 9.8 & 0.5 & 0.9 & 1.2 & 1.5 & 1.1 & 5.2 \\
\hline University & 0.1 & 0.4 & 1.8 & 1.6 & 9.8 & 13.7 & 0.1 & 0.3 & 0.7 & 0.5 & 3.4 & 5.0 \\
\hline Total & 17.8 & 21.4 & 31.5 & 10.5 & 18.8 & 100.0 & 32.8 & 30.1 & 23.5 & 5.9 & 7.8 & 100.0 \\
\hline \multicolumn{13}{|l|}{2011} \\
\hline Primary or Less & 8.8 & 4.3 & 2.4 & 0.6 & 0.2 & 16.4 & 15.3 & 7.8 & 3.3 & 1.0 & 0.2 & 27.7 \\
\hline Lower Secondary & 3.3 & 5.3 & 3.6 & 0.8 & 0.4 & 13.4 & 8.8 & 16.0 & 7.6 & 2.4 & 0.7 & 35.5 \\
\hline Upper Secondary & 2.8 & 7.2 & 17.4 & 5.7 & 5.0 & 38.2 & 2.8 & 5.8 & 8.7 & 2.2 & 1.6 & 21.1 \\
\hline Associate & 0.3 & 1.0 & 3.5 & 3.7 & 4.4 & 13.0 & 1.1 & 1.9 & 2.1 & 2.6 & 1.6 & 9.3 \\
\hline University & 0.1 & 0.5 & 2.3 & 2.4 & 13.7 & 19.0 & 0.1 & 0.4 & 0.8 & 0.8 & 4.2 & 6.3 \\
\hline Total & 15.4 & 18.3 & 29.2 & 13.3 & 23.8 & 100.0 & 28.2 & 32.0 & 22.5 & 9.0 & 8.4 & 100.0 \\
\hline
\end{tabular}

Source: Hong Kong census and by-census data. 